\title{
Evidencialidade e Modalidade como estratégia argumentativa em notícias do periódico El País sobre a pandemia do coronavírus
}

André Silva Oliveira*

Resumo: Este trabalho tem por objetivo fazer uma análise qualitativa, com base na Gramática Discursivo-Funcional, da Evidencialidade como condicionadora dos diferentes tipos de Modalidade na construção argumentativa de 30 notícias de divulgação online do periódico espanhol El País sobre a pandemia do coronavírus. Após a análise das ocorrências, constatamos que os marcadores evidenciais das camadas mais altas (Conteúdo Comunicado e Episódio) condicionam os subtipos modais das camadas mais baixas (Conteúdo Proposicional, Episódio, Estado-de-Coisas e Propriedade Configuracional) a eles, objetivando os conteúdos modais subjetivos e asseverando a objetivação dos conteúdos modais objetivos.

Palavras-chaves: Evidencialidade. Modalidade. Argumentação.

Abstract: This work aims to make a qualitative analysis, based on the Functional Discourse Grammar, of the Evidentiality as a conditioner for the different types of Modality in the argumentative construction of 30 news published online by the Spanish newspaper El País about the coronavirus pandemic. After analyzing the occurrences, we found that the evidential markers of the higher layers (Communicated Content and Episode) condition the modal subtypes of the lower layers (Propositional Content, Episode, State-of-Affairs and Configurational Property) to them, aiming at the contents subjective modals and asserting the objectification of objective modal contents.

Keywords: Evidentiality. Modality. Argumentation.

Resumen: Este trabajo tiene como objetivo hacer un análisis cualitativo, basándose en la Gramática Discursivo-Funcional, de la Evidencialidad como condicionante de los diferentes tipos de Modalidad en la construcción argumentativa de 30 noticias publicadas en línea por el periódico español El País sobre la pandemia de coronavirus. Después de analizar las ocurrencias, verificamos que los marcadores evidenciales de las capas superiores (Contenido Comunicado y Episodio) condicionan los subtipos modales de las capas inferiores (Contenido Proposicional, Episodio, Estado-de-Cosas y Propiedad Configuracional) a ellos, objetivando los contenidos modales subjetivos y aseverando la objetivación de los contenidos modales objetivos.

Palabras clave: Evidencialidad. Modalidad. Argumentación.

\footnotetext{
* Doutorando pelo Programa de Pós-Graduação em Linguística da Universidade Federal do Ceará. http://orcid.org/oooo-0003-3448-0658
} 


\section{Introdução}

Este trabalho tem por objetivo descrever e analisar o escopo de atuação dos marcadores evidenciais sobre os subtipos modais (as modalidades epistêmica, deôntica, volitiva e facultativa) no gênero notícia jornalística. Para isso, optamos pela categorização da Evidencialidade e da Modalidade proposta na Gramática DiscursivoFuncional (GDF) de Hengeveld e Mackenzie (2008). Nesse sentido, hipotetizamos que os marcadores evidenciais das camadas mais altas (Nível Interpessoal e Representacional) agem sobre os subtipos modais das camadas mais baixas (Nível Representacional) a eles, modificando ou readequando o conteúdo modal veiculado.

Para isso, selecionamos 30 notícias, em língua espanhola, alocadas na plataforma digital do jornal espanhol El País acerca da nova pandemia do coronavírus que, nos últimos dias, tem sido um dos principais assuntos abordados pelo periódico. Tendo em vista a análise qualitativa do condicionamento dos conteúdos modais em vista ao escopo de atuação dos marcadores evidenciais, pautamos os seguintes parâmetros de análise: (i) os tipos de marcadores evidenciais (Reportativo, Inferencial, Dedutivo e Perceptivo); (ii) os subtipos modais (as modalidades epistêmica, deôntica, volitiva e facultativa); e (iii) o tipo de orientação modal (Participante, Evento, Episódio e Proposição).

Do ponto de vista da organização deste trabalho, o artigo está dividido em quatro seções. Na primeira seção, apresentamos os postulados centrais da Gramática Discursivo-Funcional (GDF) e da sua proposta tipológica para a Evidencialidade e a Modalidade. Na segunda seção, discorremos acerca da Evidencialidade e da Modalidade como estratégias argumentativas. Na terceira seção, exibimos os aspectos metodológicos gerais definidos para a investigação dos marcadores evidenciais e dos subtipos modais nas notícias selecionados para a composição do universo desta pesquisa. Na quarta seção, expomos e discutimos os resultados qualitativos da descrição e análise da Evidencialidade e da Modalidade em notícias do jornal El País. Por fim, passamos às considerações finais e, em seguida, às referências deste trabalho.

\section{Evidencialidade e Modalidade na Gramática Discursivo-Funcional (GDF)}


De acordo com Hengeveld e Mackenzie (2008), a Gramática DiscursivoFuncional (GDF) consiste em um modelo descendente (top-down) de organização linguística, na qual a construção dos enunciados se inicia a partir das intenções comunicativas do falante ainda no Componente Conceitual, cuja mensagem, que ainda se encontra em sua forma pré-linguística, passa, posteriormente, para o Componente Gramatical, onde será formulada em unidades de conteúdo pragmático (no Nível Interpessoal) e semântico (no Nível Representacional) e, na sequência, codificada em unidades estruturais de natureza morfossintática (no Nível Morfossintático) e fonológica (no Nível Fonológico).

Resumidamente, com base em Hengeveld e Mackenzie (2008), o Nível Interpessoal é o responsável pelos aspectos formais que refletem o papel que as unidades linguísticas exercem na interação entre os participantes do discurso (Falante e Ouvinte) e está composto pelas seguintes camadas: Movimento $(\mathrm{M})>\operatorname{Ato} \operatorname{Discursivo}(\mathrm{A})>$ Ilocução $(\mathrm{F})>$ Participantes $(\mathrm{P})>$ Conteúdo Comunicado $(\mathrm{C})>$ Subato de Atribuição $(\mathrm{T})$ $>$ Subato Referencial (R).

Por seu turno, o Nível Representacional é o responsável pelos aspectos formais que refletem o papel que as unidades linguísticas estabelecem a partir da relação com o mundo real ou imaginário que elas descrevem, independentemente de como essas unidades linguísticas são empregadas no evento comunicativo, compondo-se das seguintes camadas: Conteúdo Proposicional $(\mathrm{p})>$ Episódio $(\mathrm{ep})>$ Estado-de-coisas $(\mathrm{e})>$ Propriedade Configuracional (f) > Propriedade Lexical > Indivíduos (x).

Por sua vez, o Nível Morfossintático é o responsável pelas propriedades lineares das unidades linguísticas em relação às estruturas das sentenças, orações e sintagmas e à parte interna das palavras mais complexas, compondo-se das seguintes camadas: Expressão Linguística $(\mathrm{Le})>$ Oração $(\mathrm{Cl})>$ Sintagma $(\mathrm{Xp})>$ Palavra $(\mathrm{Xw})>$ Base $(\mathrm{Xs})>$ Afixo (Aff).

Por seu lado, o Nível Fonológico é o responsável pela parte prosódica das unidades linguísticas em termos da expressão das funções que elas exercem na comunicação e está estruturado pelas seguintes camadas: Enunciado $(U)>$ Frase 
Entonacional $(\mathrm{IP})>$ Frase Fonológica $(\mathrm{PP})>$ Palavra fonológica $(\mathrm{PW})>$ Pé $(\mathrm{F})>$ Sílaba $(\mathrm{S})$.

Conforme Hengeveld e Mackenzie (2008), o Componente Gramatical ainda sofre influência de outros três componentes de ordem não-gramatical, a saber: (i) o Componente Conceitual, em que se desenvolvem os propósitos e as intenções comunicativas do falante para que ocorra o evento comunicativo; (ii) o Componente Contextual, em que há a descrição do conteúdo e da forma do discurso precedente; e (iii) o Componente de Saída, que é o responsável pela geração das expressões acústicas, escritas e gestuais.

Na Figura 1, podemos visualizar a arquitetura geral do modelo da GDF.

Figura 1: Esquematização Geral da GDF de Hengeveld e Mackenzie (2008)

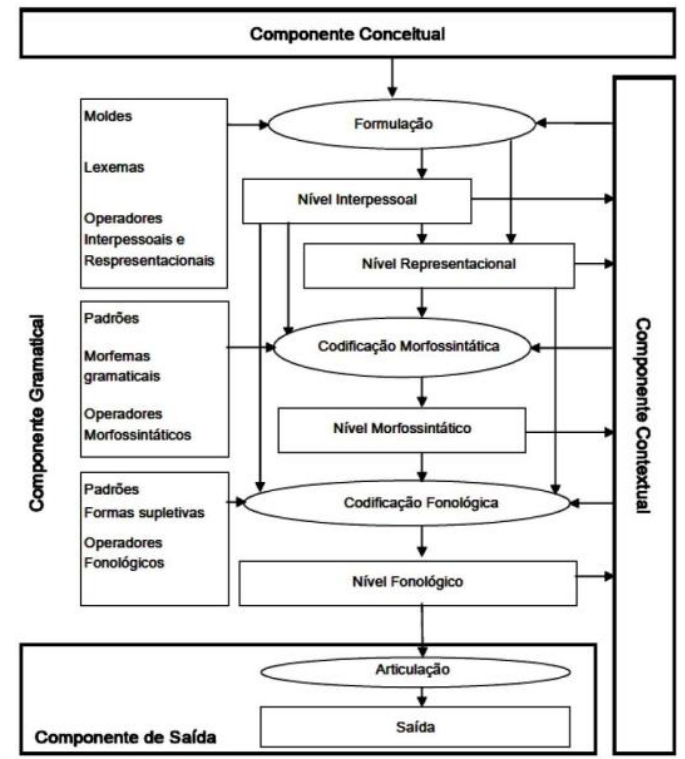

Fonte: Esquema Geral da GDF traduzido de Hengeveld e Mackenzie (20o8, p. 13)

Na GDF, a categoria Modalidade é descrita e analisada com base na tipologia das modalidades de Hengeveld (2004), em que o autor utiliza dois parâmetros principais para a delimitação e categorização dos subtipos modais, a saber: (i) o domínio semântico, que diz respeito ao tipo de avaliação que se faz do enunciado modalizado; e (ii) a orientação modal, que diz respeito à perspectiva sobre a qual recai o enunciado modalizado. 
Em relação ao primeiro parâmetro, a Modalidade pode ser dividida em quatro tipos: (i) facultativa, que diz respeito às capacidades e às habilidades intrínsecas ou adquiridas; (ii) deôntica, que diz respeito ao que é moralmente, legalmente e socialmente aceito em termos de regras e normas de conduta; (iii) epistêmica, que é relativa aos conhecimentos, aos saberes e às crenças acerca do mundo real; e (iv) volitiva, que diz respeito ao que é (in)desejável.

No tocante ao segundo parâmetro, a Modalidade pode estar orientada para: (i) o Participante, que se refere à relação entre (ou as propriedades de) um participante e um evento e a potencialização de realização desse evento; (ii) o Evento, que se trata da avaliação objetiva de um evento, ou seja, a parte descrita de um estado-de-coisas em um enunciado; e (iii) a Proposição, que é relativa à parte do enunciado que representa as visões, as crenças e os desejos pessoais do falante, sendo, portanto, referente à especificação do grau de comprometimento do falante com relação à proposição que ele apresenta. Em Hengeveld (2011) e Hengeveld e Hattnher (2015), há a inclusão da orientação modal para o Episódio, em que o falante avalia a (im)possibilidade de ocorrência de um único estado-de-coisas ou de um conjunto de estado-de-coisas tematicamente coerentes e sob o escopo de um tempo absoluto.

A proposta de categorização da Modalidade de Hengeveld (2004) é introduzida na GDF de Hengeveld e Mackenzie (2008), em que se considera a inserção das categorias modais em níveis e camadas e com base na atuação das diferentes modalidades dentro do Nível Representacional. Dessa forma, os diferentes subtipos modais (as modalidades epistêmica, deôntica, volitiva e facultativa) estão alocados nas quatro camadas (Propriedade Configuracional, Estado-de-Coisas, Episódio e Conteúdo Proposicional) de acordo com o seu escopo de atuação. Assim, nas camadas da Propriedade Configuracional e do Estado-de-Coisas, encontram-se os modalizadores deônticos, facultativos e volitivos. Por sua vez, na camada do Conteúdo Proposicional estão alocados os modalizadores epistêmicos. Em Hengeveld e Hattnher (2015), há a delimitação da modalidade orientada para o Episódio, por isso, passa-se a considerar a existência de modalizadores epistêmicos atuando na camada do Episódio. 
Em Hengeveld e Mackenzie (2008), a Evidencialidade é tratada como uma categoria linguística diferenciada da Modalidade, ${ }^{1}$ referindo-se à fonte da informação que é apontada pelo falante em seu discurso (na GDF, o discurso é dito como o uso efetivo da língua em um contexto de interação específico). Em trabalhos posteriores, tais como Hengeveld e Hattnher (2015) e Hattnher (2018), há uma readequação da proposta de categorização dos tipos evidenciais, em que os autores dividem a Evidencialidade em quatro tipos: (i) Reportativa, que opera na camada do Conteúdo Comunicado (Nível Interpessoal), referindo-se que o falante não expressa o seu próprio conhecimento acerca dos fatos, mas que está repassando as informações que são obtidas por terceiros; (ii) Inferencial, que opera na camada do Conteúdo Proposicional (Nível Representacional), sendo relativa à manifestação dos fatos com base nos conhecimentos prévios do próprio falante, ou seja, este expressa o seu próprio material cognitivo; (iii) Dedutiva, que opera na camada do Episódio (Nível Representacional), tratando-se da indicação da ocorrência de um episódio (conjunto de estado-de-coisas tematicamente coerentes e sob o escopo de um tempo absoluto) que é deduzido pelo falante com base em alguma evidência disponível, mas sem que ele tenha testemunhado o episódio relatado, sendo capaz de deduzi-lo com base na percepção de alguma evidencia resultante; e (iv) Perceptiva, que opera na camada do Estado-de-Coisas (Nível Representacional), estando relacionada à indicação de um evento testemunhado ou não pelo falante.

Dessa forma, com base na GDF, constatamos que a Evidencialidade (a fonte da informação) e a Modalidade (a manifestação dos posicionamentos do falante perante o que é enunciado por ele) podem ser descritas e analisadas com base no escopo de atuação dentro do Nível Representacional (marcadores evidenciais e modalizadores) e no Nível Interpessoal (marcadores evidenciais) a partir da camada de atuação em que estes marcadores/modalizadores atuam. Ainda conforme o modelo da GDF, é possível que marcadores evidenciais de camadas mais altas tenham um escopo de atuação sobre

\footnotetext{
'No arcabouço teórico da Gramática Discursivo-Funcional (GDF), modelo teórico adotado nesta pesquisa, a Evidencialidade e a Modalidade são interpretadas como categorias linguísticas distintas, em que a primeira se refere à fonte da informação, enquanto a segunda diz respeito ao posicionamento do falante em relação ao que é enunciado por ele a partir de suas crenças e opiniões subjetivas.
} 
modalizadores de camadas mais baixas. Nesse sentido, é completamente possível que as diferentes categorias evidenciais condicionem ou readéquem o comportamento dos subtipos modais relativos às modalidades epistêmica, deôntica, volitiva e facultativa.

Sabendo-se da especificação e da categorização da Evidencialidade e da Modalidade na GDF, passaremos, na seção seguinte, para a abordagem dessas categorias linguísticas como estratégias argumentativas.

\section{Evidencialidade e Modalidade como estratégia argumentativa}

De acordo com Carioca (2018), a forma como as pessoas se comunicam pode relevar muito acerca dos seus propósitos e intenções comunicativas, considerando que as informações veiculadas no discurso (tomando a perspectiva da GDF, que especifica o discurso como o uso efetivo da língua em um contexto de interação verbal) podem ter o falante como fonte dessa informação (Evidencialidade Inferencial) ou outros tipos de fonte que são introjetadas por meio de marcas contidas no enunciado (Evidencialidade Reportativa). Segundo a autora, ao fazer uso dessas marcas de indicação da fonte, o falante pode reforçar ou certificar como "certo", "plausível”, "relevante” o que é comunicado, recorrendo, dessa forma, à Evidencialidade que, por sua vez, refere-se à fonte da informação.

Para Carioca (2018), a Evidencialidade serve como estratégia discursiva e argumentativa na construção do texto para um maior ou menor comprometimento com a proposição que se deseja considerar, o que, em certa medida, promove a indicação da fonte em relação ao conhecimento que é manifestado, o que determina o grau de tensão que se estabelece entre o falante (autor da notícia) e o ouvinte (os leitores da notícia). Por isso, é necessário que o falante saiba utilizar de forma adequada os marcadores evidenciais, no intuito de promover o desenvolvimento de uma relação direta entre o grau de envolvimento dele com aquilo que ele está querendo dizer. Desse modo, o falante deve ser capaz de fornecer os subsídios necessários que permitam a correta interpretação da mensagem proposta que, por seu lado, é oriunda de uma fonte que se responsabiliza pelo que é dito. 
No que se refere à Modalidade, Lourenço (2017) especifica que ela se refere à qualificação que o falante faz em seus enunciados de forma a refletir o seu julgamento pessoal (subjetividade) acerca da proposição ou constatativo (objetividade) sobre eventos, manifestando, portanto, seu ponto de vista sobre o que é dito. No intuito de reforçar as suas avaliações ou constatações (Modalidade), o falante pode recorrer a outras categorias linguísticas, dentre elas destacamos a Evidencialidade (a fonte da informação). De acordo com Carioca (2018), as qualificações modais (epistêmica, deôntica, volitiva e facultativa) são, geralmente, baseadas em evidências, variando apenas na qualidade dessa evidência, que pode se tratar de um agente moralmente responsável (o que faz com que a qualificação modal seja mais assertiva) ou de um sujeito sem as qualificações necessárias para isso (o que torna a qualificação modal menos assertiva). Com base no autor, tudo que é veiculado no discurso pode ter o falante como fonte da informação (Inferencial, Dedutiva ou Perceptiva) ou um outro tipo de fonte que não o falante (Reportativa).

Dessa forma, inferimos que seja possível que a Evidencialidade possa ser uma estratégia argumentativa que condicione a instauração da Modalidade no discurso. Conforme Arena (2015), há um tripé discursivo (Argumentação, Modalidade e Evidencialidade) que constitui o que se denomina de motivações pragmáticodiscursivas, em que a língua é usada a fim de que os sujeitos possam interagir socialmente por meio dos seus discursos, sendo, portanto, as unidades linguísticas engendradas no encadeamento discursivo como forma de ação sobre o mundo, os sujeitos, os acontecimentos, etc., dotadas sempre de intencionalidades, o que, em certa medida, caracteriza a argumentatividade.

Por fim, com base em Arena (2015), entendemos que o ato de argumentar é fundamental para todas as ações verbais humanas, sejam elas escritas ou orais, haja vista que os sujeitos, por serem dotados de razão e vontade, podem, constantemente, avaliarem, julgarem, criticarem, apoiarem ou formarem juízos de valor. Assim, por meio do gênero notícia, ponderamos que o autor possa tentar influir sobre o comportamento dos leitores ao compartilhar fatos e opiniões como forma de convencimento/persuasão (o que é delimitado, nesta pesquisa, como sinônimos). 
Tendo sido feita a consideração acerca da argumentatividade das categorias Evidencialidade e Modalidade, passaremos, na seção seguinte, para a metodologia que irá nortear esta pesquisa.

\section{Metodologia}

Para esta pesquisa, selecionamos 30 notícias, escritas em língua espanhola, sobre a pandemia do coronavírus e veiculadas na plataforma digital do jornal espanhol El País, disponível em: <https://elpais.com>, com data de acesso em: 19 mar. 2020. As notícias, de um modo geral, faziam referência à situação da nova doença na Espanha, à quantidade de pessoas infectadas e hospitalizadas, às medidas do governo espanhol para combater ou frear a doença e o surgimento de novos casos, às medidas preventivas tomadas pelo Ministério da Saúde, à quantidade de falecidos por causa do coronavírus, em suma, foram selecionadas as 30 notícias mais recentes sobre esta nova doença (todas elas relativas ao período de fevereiro a março de 2020). ${ }^{2}$

Em relação ao gênero jornalístico notícia, de acordo com Lourenço (2017), ele se configura como um tipo de gênero jornalístico fundamental e básico dos jornais, seguindo, geralmente, uma estrutura convencional, cuja função é essencialmente informativa, pois é produzida no intuito de se relatar os fatos de um evento, pondo em foco, de forma clara e concisa, os principais acontecimentos relativos ao evento noticiado. Segundo a autora, é comum que as notícias tragam a(s) fonte(s) das informações que são veiculadas, apresentando o ponto de vista de um sujeito (terceiroreportado) introjetado no discurso. Assim, conforme a autora, quando se repassa as declarações de outras pessoas (podendo também ser instituições) que possam estar envolvidas de alguma forma com o que está sendo noticiado, isso poderia funcionar como uma estratégia argumentativa que garantisse a objetividade e imparcialidade do texto, na medida em que se pretenda isentar da responsabilidade sobre as declarações de outrem (terceiro-reportado).

\footnotetext{
${ }^{2}$ As notícias veiculadas pelo periódico espanhol são de livre acesso a todos aqueles interessados em seu conteúdo e disponibilizadas gratuitamente na plataforma digital do jornal.
} 
Desse modo, acreditamos que o gênero jornalístico notícia seja propício ao engendramento da categoria Evidencialidade que, por seu turno, pode funcionar como uma estratégia de mudança das qualificações modais que são apresentadas no encadeamento discursivo do texto (notícia). Com base nisso, ponderamos que os marcadores evidenciais (Reportativos, Inferenciais, Dedutivos ou Perceptivos) possam condicionar os subtipos modais (as modalidades epistêmica, deôntica, volitiva e facultativa). Assim, propomos como parâmetros de análise: (i) os marcadores de Evidencialidade (Reportativa, Inferencial, Dedutiva e Perceptiva); (ii) os tipos de Modalidade (epistêmica, deôntica, volitiva e facultativa); e (iii) o tipo de orientação modal (Participante, Evento, Episódio e Proposição).

Sabendo-se da caracterização do corpus, da especificação do gênero notícia e da apreciação das categorias de análise, passaremos, na seção seguinte, para os resultados e as discussões referentes à análise qualitativa da Evidencialidade e da Modalidade nas notícias do jornal El País.

\section{Resultados e discussões}

Nesta seção, exporemos a descrição e a análise qualitativa da categoria Evidencialidade como condicionadora da Modalidade (epistêmica, deôntica, volitiva e facultativa) nas notícias do periódico El País sobre a pandemia do coronavírus.

Ponderamos que os marcadores evidenciais podem condicionar os diferentes tipos de Modalidade, mudando o conteúdo modal veiculado; podendo também, em termos de argumentação e discursividade, reforçar os fatos que são veiculados na notícia, asseverar crenças e opiniões, pontuar as circunstâncias externas que capacitem a concretização de eventos, bem como regular ou prescrever normas e regras de conduta e manifestar desejos, vontades e intenções. Nesse sentido, pensamos que, em virtude de o gênero notícia ser de caráter objetivo (assertivo e enfático quanto aos fatos e às opiniões veiculadas), seja possível que os marcadores evidenciais atuem como condicionadores dos subtipos modais, atenuando ou asseverando o grau de objetivação dos enunciados modalizados. 
Com base nisso, acreditamos que marcadores evidenciais, que operam em camadas mais altas (Conteúdo Comunicado, Conteúdo Proposicional, Episódio e Estado-de-Coisas), possam ter um escopo de atuação sobre os subtipos modais de camadas mais baixas (Conteúdo Proposicional, Episódio, Estado-de-Coisas e Propriedade Configuracional), como veremos nas subseções seguintes.

\subsection{Evidencialidade e modalidade epistêmica}

Em relação à Evidencialidade e à modalidade epistêmica, constatamos que os marcadores evidenciais, que operam na camada do Conteúdo Comunicado (Evidencialidade Reportativa), apresentam um escopo de atuação sobre modalizações epistêmicas com orientação para a Proposição (Conteúdo Proposicional), o Episódio (Episódio) e o Evento (Estado-de-Coisas), como podemos ver, respectivamente, nas ocorrências de (1) a (3):

(1) Explica Alfonso, vecino de Hombrados. Un paseo por cualquiera de estos pueblos confirma lo anunciado. Un gato despistado es todo lo que el visitante puede encontrarse. "Creo que aquí a la gente le cuesta menos obedecer porque estamos acostumbrados". ${ }^{3}$

(2) La Generalitat considera que el sistema sanitario de Cataluña puede "entrar en estrés" este fin de semana a consecuencia del aumento de los casos de coronavirus. ${ }^{4}$

(3) "Hay mucho que no se conoce del virus y estas predisposiciones pueden interactuar con la biología del virus, favoreciéndolo de alguna manera, y en otras ocasiones protegiéndonos", añade Ayllón. ${ }^{5}$

Em (1), identificamos um caso de modalidade epistêmica com orientação para a Proposição que, de acordo com Hengeveld (2004), refere-se ao comprometimento do

\footnotetext{
3Tradução livre: Explica Alfonso, um vizinho de Hombrados. Uma caminhada por qualquer uma dessas cidades confirma o que foi anunciado. Um gato sem noção é tudo o que o visitante pode encontrar. "Acho que as pessoas aqui têm menos problemas para obedecer porque estamos acostumados a isso". Disponível em: <https://elpais.com/sociedad/2020-03-17/la-espana-que-ya-estaba-encuarentena.html>. Acesso em: 19 mar. 2020.

4Tradução livre: A Generalitat considera que o sistema de saúde catalão pode "entrar em estresse" neste fim de semana como resultado do aumento nos casos de coronavírus. Disponível em: <https://elpais.com/espana/catalunya/2020-03-19/la-generalitat-movilizara-loslicenciados-de-medicinay-medicos-jubilados-para-luchar-contra-elcoronavirus.html>. Acesso em: 19 mar. 2020.

5Tradução livre: "Não se sabe muito sobre o vírus e essas predisposições podem interagir com a biologia do vírus, favorecendo-o de alguma forma e outras vezes nos protegendo", acrescenta Ayllón. Disponível em: <https://elpais.com/sociedad/2020-03-18/joven-sano-y-en-la-uci-el-riesgoexiste.html>. Acesso em: 19 mar. 2020.
} 
falante com relação ao que é dito, tendo em vista as suas crenças e visões acerca do mundo real. Nesse caso, acreditamos que o escopo de atuação de um marcador evidencial de Reportatividade possa apresentar, de maneira objetiva [+objetivação], a proposição que é inferida e avaliada pelo sujeito introjetado no discurso, no caso, Alfonso, ao expressar sua crença (modalizada por meio do verbo creer na primeira pessoa do singular) de que as pessoas não imponham resistência em obedecer as novas regras quando já estão acostumadas a elas.

Em (2), verificamos um caso de modalidade epistêmica com orientação para o Episódio que, segundo Hengeveld e Hattnher (2015), trata-se da (im)possibilidade de concretização de um evento (composto por dois ou mais estados-de-coisas coerentemente concatenados) sob o escopo de um tempo absoluto. Nesse caso, temos que o marcador de Evidencialidade Reportativa, ao ter um escopo de atuação sobre uma modalidade epistêmica orientada para o Episódio, parece indicar uma dupla objetivação [++objetivação] em relação ao que é reportado pelo sujeito introjetado no discurso ( $L a$ Generalitat) e ao estatuto objetivo do estado-de-coisas que é apresentado por esse mesmo sujeito (el sistema sanitario de Cataluña puede entrar en estrés), em que este estado-de-coisas está sob o escopo de um tempo absoluto (este fin de semana).

Em (3), constatamos um caso de modalidade epistêmica orientada para o Evento que, conforme Hengeveld (2004), diz respeito ao estatuto objetivo de um evento em relação à possibilidade de ocorrência desse evento no mundo, a partir do que já é conhecido e sabido. Nesse caso, ponderamos que haja uma tripla objetivação [+++objetivação] do conteúdo cognitivo reportado pelo falante (produtor da notícia). Nesse sentido, ao empregar um marcador de Evidencialidade Reportativa, que incide sobre a modalidade epistêmica orientada para o Evento, o falante busca: marcar o que é reportado pelo sujeito introjetado no discurso (añade Ayllón), revelar a forma de obtenção do conteúdo veiculado (Hay mucho que no se conoce del virus) e apontar o estatuto objetivo do evento passível de ocorrer no mundo real (estas predisposiciones pueden interactuar con la biología del virus).

No que tange à Evidencialidade Dedutiva, cujos marcadores evidenciais atuam na camada do Episódio, constatamos apenas casos de escopo de atuação sobre modalizações epistêmicas com orientação para o Evento, como na ocorrência (4): 
(4) Con comunidades de 30 o 40 habitantes y sin apenas contacto con el exterior, el coronavirus podría parecer una lejana amenaza urbanita. ${ }^{6}$

Em (4), o falante (produtor da notícia) manifesta, em seu discurso, o conhecimento prévio acerca da situação dos povoados na Espanha e da falta de contato com o mundo externo, no caso, os grandes centros urbanos (Con comunidades de 300 40 habitantes y sin apenas contacto con el exterior), expressando, com base nisso, o estatuto objetivo da possibilidade de ocorrência de um evento no mundo real (el coronavirus podría parecer una lejana amenaza urbanita). Acreditamos que haja menor grau de objetivação [-objetivação] com relação ao conteúdo veiculado na notícia, em virtude de o falante expor o conhecimento prévio e, com base nele, ele próprio fazer uma ponderação (dedução) da possibilidade de concretização do evento, o que é asseverado pelo emprego do condicional simples do espanhol ao utilizar o modalizador epistêmico poder (podría).

Em suma, apresentamos o Quadro 1 com as considerações acerca da Evidencialidade e da modalidade epistêmica:

Quadro 1: Evidencialidade e modalidade epistêmica

\begin{tabular}{|c|c|c|}
\hline Marcador de Evidencialidade & Orientação modal epistêmica & $\begin{array}{c}\text { Grau de objetivação e } \\
\text { escopo de atuação do } \\
\text { marcador evidencial }\end{array}$ \\
\hline $\begin{array}{c}\text { Reportativa } \\
\text { (Conteúdo Comunicado) }\end{array}$ & $\begin{array}{c}\text { Modalidade epistêmica orientada } \\
\text { para a Proposição } \\
\text { (Conteúdo Proposicional) }\end{array}$ & $\begin{array}{c}\text { [+objetivação] } \\
{[\mathrm{C}>\mathrm{p}]}\end{array}$ \\
\hline $\begin{array}{c}\text { Reportativa } \\
\text { (Conteúdo Comunicado) }\end{array}$ & $\begin{array}{c}\text { Modalidade epistêmica orientada } \\
\text { para o Episódio } \\
\text { (Episódio) }\end{array}$ & $\begin{array}{c}\text { [++objetivação }] \\
{[C>\text { ep }]}\end{array}$ \\
\hline $\begin{array}{c}\text { Reportativa } \\
\text { (Conteúdo Comunicado) }\end{array}$ & $\begin{array}{c}\text { Modalidade epistêmica orientada } \\
\text { para o Evento } \\
\text { (Estado-de-Coisas) }\end{array}$ & $\begin{array}{c}{[+++ \text { objetivação }]} \\
{[C>\text { e }]}\end{array}$ \\
\hline $\begin{array}{l}\text { Dedutiva } \\
\text { (Episódio) }\end{array}$ & $\begin{array}{c}\text { Modalidade epistêmica orientada } \\
\text { para o Evento } \\
\text { (Estado-de-Coisas) }\end{array}$ & $\begin{array}{c}\text { [-objetivação] } \\
{[\text { ep }>\text { e] }}\end{array}$ \\
\hline
\end{tabular}

Fonte: Elaborado pelo autor

\footnotetext{
${ }^{6}$ Tradução livre: Com comunidades de 30 ou 40 habitantes e com pouco contato com o exterior, o coronavírus pode parecer uma ameaça urbana distante. Disponível em: <https://elpais.com/sociedad/2020-03-17/la-espana-que-ya-estaba-encuarentena.html>. Acesso em: 19 mar. 2020.
} 
Sabendo-se dos casos de Evidencialidade e modalidade epistêmica, passaremos, na subseção seguinte, para os casos de Evidencialidade e modalidade deôntica.

\subsection{Evidencialidade e modalidade deôntica}

Em relação à Evidencialidade e à modalidade deôntica, constatamos que os marcadores evidenciais, que operam na camada do Conteúdo Comunicado (Evidencialidade Reportativa), apresentam um escopo de atuação sobre modalizações deônticas com orientação para o Evento (Estado-de-Coisas) e o Participante (Propriedade Configuracional), como podemos ver, respectivamente, nas ocorrências (5) a (6):

(5) "El enemigo es el virus. Llamo a la unidad política y ciudadana. Una pandemia no distingue colores e ideas y debe ser combatida por todos. Agradezco la respuesta de los partidos, la superación de las diferencias ennoblece la política, todas las comunidades están a la altura para hacer su tarea", ha señalado Sánchez. ${ }^{7}$

(6) "Existe una clamorosa infranotificación de casos", sostiene Pere Godoy, presidente de la Sociedad Española de Epidemiología (SEE). "Esta es una de las primeras cuestiones a resolver y el problema no es solo de Madrid. Necesitamos hacer más pruebas para gestionar mejor la epidemia", añade Godoy. ${ }^{8}$

Em (5), constatamos um caso de modalidade deôntica orientada para o Evento que, de acordo com Hengeveld (2004), diz respeito à obrigatoriedade ou à permissividade de realização de um evento, mas sem que o falante faça uma avaliação pessoal dele. Nesse caso, atestamos que o marcador de Evidencialidade Reportativa, ao ter um escopo de atuação sobre a modalidade deôntica orientada para o Evento, parece indicar uma dupla objetivação [++objetivação], no tocante ao que é reportado pelo

\footnotetext{
7Tradução livre: "O inimigo é o vírus. Apelo à união política e cidadã. Uma pandemia não distingue cores e ideias e deve ser combatida por todos. Agradeço a resposta dos partidos, a superação das diferenças enobrece a política, todas as comunidades estão à altura da tarefa", afirmou Sánchez. Disponível em: $<$ https://elpais.com/cultura/2020-03-17/la-pandemia-del-coronavirus-aboca-alsector-editorial-a-uncambio-de-modelo.html>. Acesso em: 19 mar. 2020.

${ }^{8}$ Tradução livre: "Há uma subnotificação clamorosa de casos", diz Pere Godoy, presidente da Sociedade Espanhola de Epidemiologia (SEE). "Esta é uma das primeiras perguntas a serem resolvidas e o problema não é apenas de Madri. Precisamos fazer mais testes para gerenciar melhor a epidemia ", acrescenta Godoy. Disponível em: <https://elpais.com/sociedad/2020-03-18/lunes-un-muerto-cada-16-minutos-enloshospitales-de-madrid.html>. Acesso em: 19 mar. 2020.
} 
sujeito introjetado no discurso (Sánchez) e ao estatuto objetivo do evento sobre o qual recai a deonticidade (valor modal deôntico) expressa (El enemigo es el virus. Llamo a la unidad política y ciudadana. Una pandemia no distingue colores e ideas y debe ser combatida por todos).

Em (6), averiguamos um caso de modalidade deôntica orientada para o Participante que, segundo Hengeveld (2004), está relacionada à obrigação ou à permissão que recai sobre um participante de realizar o evento que é descrito pelo predicado. Nesse caso, constatamos que o marcador de Evidencialidade Reportativa (sostiene Pere Godoy), ao ter um escopo de atuação sobre a modalidade deôntica com orientação para o Participante, parece também apontar para uma dupla objetivação [++objetivação], haja vista que o falante (produtor da notícia) veicula o que é reportado pelo sujeito introjetado no discurso (Pere Godoy) que, por sua vez, age como um "portavoz" da deonticidade expressa (Necesitamos hacer más pruebas para gestionar mejor la epidemia).

No que diz respeito à Evidencialidade Dedutiva, cujos marcadores evidenciais atuam na camada do Episódio, constatamos apenas casos de escopo de atuação sobre modalizações deônticas orientadas para o Evento e o Participante, como podemos averiguar, respectivamente, nas ocorrências (7) e (8):

(7) La pandemia de coronavirus ha puesto patas arriba el día a día de los hospitales. El aluvión de casos graves ha saturado las unidades de cuidados intensivos (UCI) y una cama en ese servicio se cotiza al alza. El objetivo es contener el virus y todo lo que no sea eso o emergencias vitales, puede esperar. ${ }^{9}$

(8) Con un virus nuevo circulando por dentro y fuera de los hospitales, los médicos tienen que asegurarse de que un eventual donante no ha contraído la infección en ningún momento y está libre de coronavirus. ${ }^{10}$

\footnotetext{
${ }^{9}$ Tradução livre: A pandemia de coronavírus virou o dia-a-dia dos hospitais de cabeça para baixo. A enxurrada de casos graves tem unidades de terapia intensiva saturadas (UTI), e um leito nesse serviço está sendo negociado mais alto. O objetivo é conter o vírus e qualquer coisa diferente disso ou emergências vitais podem esperar. Disponível em: <https://elpais.com/sociedad/2020-03-17/la-crisis-del-coronaviruspasa-facturaa-los-trasplantes.html>. Acesso em: 19 mar. 2020.

${ }^{10}$ Tradução livre: Com um novo vírus circulando dentro e fora dos hospitais, os médicos precisam garantir que um eventual doador não contraia a infecção a qualquer momento e esteja livre de coronavírus. Disponível em: <https://elpais.com/sociedad/2020-03-17/la-crisis-del-coronavirus-pasa-facturaa-lostrasplantes.html>. Acesso em: 19 mar. 2020.
} 
Em (7), a modalidade deôntica está orientada para o Evento e está sob o escopo de atuação de um marcador de Evidencialidade Dedutiva, em que o falante (produtor da notícia) aponta para o que é sabido (La pandemia de coronavirus ha puesto patas arriba el día a día de los hospitales. El aluvión de casos graves ha saturado las unidades de cuidados intensivos (UCI) y una cama en ese servicio se cotiza al alza) e, com base no que é conhecido a partir dos fatos, reporta a permissividade do evento (todo lo que no sea eso o emergencias vitales, puede esperar), baseando-se no que é por ele deduzido, sendo, portanto, de um menor grau de objetivação [-objetivação].

Em (8), a modalidade deôntica está orientada para o Participante e também está sob o escopo de um marcador de Evidencialidade Dedutiva, em que o falante (produtor da notícia) marca, em seu encadeamento discursivo, o que é conhecido em termos da nova pandemia (Con un virus nuevo circulando por dentro y fuera de los hospitales), para, com base nisso, atuar como um "porta-voz" da deonticidade manifestada no enunciado modalizado (los médicos tienen que asegurarse de que un eventual donante no ha contraído la infección en ningún momento y está libre de coronavírus). Nesse caso, também constatamos que há um menor grau de objetivação do conteúdo veiculado na notícia [-objetivação].

Para além do que já é previsto em Hengeveld (2004) e Hengeveld e Mackenzie (2008), ponderamos que os marcadores evidenciais, especificamente os de Evidencialidade Reportativa, possam também alocar os modalizadores deônticos em camadas mais altas do Nível Representacional, designadamente na camada do Episódio, como podemos ver na ocorrência (9):

(9) Ahora, con el enemigo ya dentro, los centros luchan por defenderse. "Las residencias de mayores no son el lugar adecuado para atender a las personas que dan positivo", advierte Juan José García Ferrer, secretario general de Lares, una asociación que agrupa a casi 1.0oo residencias de España. "Es lo primero que tenían que haber protegido, pero se han olvidado"."

\footnotetext{
"Tradução livre: Agora, com o inimigo já dentro, os centros lutam para se defender. "Os lares de idosos não são o lugar certo para cuidar de pessoas com resultados positivos", diz Juan José García Ferrer, secretário geral da Lares, uma associação que reúne quase mil lares de idosos na Espanha. "É a primeira coisa que eles deveriam ter protegido, mas esqueceram". Disponível em: <https://elpais.com/espana/madrid/2020-03-18/las-residencias-se-convierten-enmorgues-no-querianque-viera-los-cadaveres-en-las-bolsas-color-crema.html>. Acesso em: 19 mar. 2020.
} 
Em (9), o marcador de Evidencialidade Reportativa tem um escopo de atuação sobre a modalidade deôntica orientada para o Episódio que, para esta pesquisa, pode ser definida como a avaliação pessoal do falante (nesse caso, o sujeito introjetado no discurso pelo produtor da notícia) acerca das obrigações que são inerentes ao participante expresso pelo predicado em um momento que é anterior ao evento de fala (preteridade). Nesse sentido, deparamo-nos com um caso em que o falante (produtor da notícia) reporta o que é avaliado pelo sujeito introjetado no discurso (Juan José García Ferrer) em relação ao evento sobre o qual recai a deonticidade (haber protegido a las residências de mayores), estando este evento sobre o escopo de um tempo absoluto (o que é marcado pelo emprego do pretérito imperfeito do indicativo, tenían). Nesses casos, o falante busca objetivar, considerando que o intuito de produção de uma notícia é a de mostrar os fatos e opiniões de forma mais pontual e assertiva, as crenças do sujeito introjetado no discurso, indicando, dessa forma, certo grau de objetivação [+objetivação], pois se refere ao material cognitivo de outrem e com base nas crenças e opiniões do sujeito introjetado.

Resumidamente, apresentamos o Quadro 2 com as considerações acerca da Evidencialidade e da modalidade deôntica:

Quadro 2: Evidencialidade e modalidade deôntica

\begin{tabular}{|c|c|c|}
\hline Marcador de Evidencialidade & Orientação modal deôntica & $\begin{array}{l}\text { Grau de objetivação e } \\
\text { escopo de atuação do } \\
\text { marcador evidencial }\end{array}$ \\
\hline $\begin{array}{c}\text { Reportativa } \\
\text { (Conteúdo Comunicado) }\end{array}$ & $\begin{array}{c}\text { Modalidade deôntica orientada } \\
\text { para o Episódio } \\
\text { (Episódio) }\end{array}$ & $\begin{array}{c}\text { [+objetivação] } \\
{[C>\text { ep }]}\end{array}$ \\
\hline $\begin{array}{c}\text { Reportativa } \\
\text { (Conteúdo Comunicado) }\end{array}$ & $\begin{array}{c}\text { Modalidade deôntica orientada } \\
\text { para o Evento } \\
\text { (Estado-de-Coisas) }\end{array}$ & $\begin{array}{c}{[++ \text { objetivação }]} \\
{[\mathrm{C}>\mathrm{e}]}\end{array}$ \\
\hline $\begin{array}{c}\text { Reportativa } \\
\text { (Conteúdo Comunicado) }\end{array}$ & $\begin{array}{c}\text { Modalidade deôntica orientada } \\
\text { para o Participante } \\
\text { (Propriedade Configuracional) }\end{array}$ & $\begin{array}{c}{[++ \text { objetivação }]} \\
{[\mathrm{C}>\mathrm{f}]}\end{array}$ \\
\hline $\begin{array}{l}\text { Dedutiva } \\
\text { (Episódio) }\end{array}$ & $\begin{array}{c}\text { Modalidade deôntica orientada } \\
\text { para o Evento } \\
\text { (Estado-de-Coisas) }\end{array}$ & $\begin{array}{c}\text { [-objetivação] } \\
{[\text { ep }>\text { e] }}\end{array}$ \\
\hline $\begin{array}{l}\text { Dedutiva } \\
\text { (Episódio) }\end{array}$ & $\begin{array}{c}\text { Modalidade deôntica orientada } \\
\text { para o Participante } \\
\text { (Propriedade Configuracional) }\end{array}$ & $\begin{array}{c}\text { [-objetivação] } \\
{[\text { ep }>\text { f] }}\end{array}$ \\
\hline
\end{tabular}

Fonte: Elaborado pelo autor 
Sabendo-se dos casos de Evidencialidade e modalidade deôntica, passaremos, na subseção seguinte, para os casos de Evidencialidade e modalidade volitiva.

\subsection{Evidencialidade e modalidade volitiva}

Em relação à Evidencialidade e à modalidade volitiva, constatamos que os marcadores evidenciais, que operam na camada do Conteúdo Comunicado (Evidencialidade Reportativa), apresentam um escopo de atuação sobre modalizações volitivas com orientação para o Evento (Estado-de-Coisas) e o Participante (Propriedade Configuracional), como podemos ver, respectivamente, nas ocorrências (10) e (11):

(10) Los matices se encuentran en cómo dar salida a los títulos de una programación que suele cerrarse con al menos un año o hasta 15 meses de adelanto. PRH no descarta que se intenten recolocar títulos en un efecto dominó, que podría convertir julio - "Si lo pactamos con las librerías", aseguran - en un mes con novedades, lo que no es nada habitual. ${ }^{12}$

(11) "Queremos movilizar todos los medios posibles", ha dicho en rueda de prensa la consejera de Salud, Alba Vergés. ${ }^{13}$

Em (10), constatamos um caso de modalidade volitiva orientada para o Evento que, de acordo com Hengeveld (2004), diz respeito à desejabilidade de concretização de um evento, mas sem que o falante faça uma avaliação pessoal dele. Nesse caso, atestamos que o marcador de Evidencialidade Reportativa, ao ter um escopo de atuação sobre a modalidade volitiva orientada para o Evento, parece indicar uma dupla objetivação [++objetivação] em termos de argumentatividade na notícia veiculada, no tocante ao que é reportado pelo sujeito introjetado no discurso $(P R H)$ e ao estatuto objetivo do evento sobre o qual recai a volitividade (valor modal volitivo) expressa (que se intenten

\footnotetext{
${ }^{12}$ Tradução livre: As nuances são encontradas em como produzir os títulos de um programa que geralmente fecha com pelo menos um ano ou até 15 meses de antecedência. O PRH não descarta tentar realocar títulos em um efeito dominó, que pode transformar julho - "se concordarmos com as livrarias", dizem eles - em um mês com notícias, o que não é comum. Disponível em: <https://elpais.com/cultura/2020-03-17/la-pandemia-del-coronavirus-aboca-alsector-editorial-a-uncambio-de-modelo.html>. Acesso em: 19 mar. 2020.

${ }^{13}$ Tradução livre: "Queremos mobilizar todos os meios possíveis", afirmou em entrevista coletiva o ministro da Saúde, Alba Vergés. Disponível em: <https://elpais.com/espana/catalunya/2020-03-19/la-generalitatmovilizara-loslicenciados-de-medicina-y-medicos-jubilados-para-luchar-contra-elcoronavirus.html>. Acesso em: 19 mar. 2020.
} 
recolocar títulos en un efecto dominó) que, por sua vez, é reportado no discurso na fala do sujeito introjetado.

Em (11), averiguamos um caso de modalidade volitiva orientada para o Participante que, segundo Hengeveld (2004), está relacionada à manifestação dos desejos, vontades ou intenções do participante designado pelo predicado em concretizar o evento sobre o qual recai a volição. Nesse caso, constatamos que o marcador de Evidencialidade Reportativa, ao ter um escopo de atuação sobre a modalidade volitiva com orientação para o Participante, parece também apontar para uma dupla objetivação [++objetivação] no que diz respeito à discursividade do falante (produtor da notícia), haja vista que ele veicula o que é reportado pelo sujeito introjetado no discurso (Alba Vergés) que, por sua vez, manifesta o desejo coletivo (o que é evidenciado pela marca de primeira pessoa do plural, nosotros) em relação ao evento desejado (movilizar todos los medios posibles).

Para além do que já é previsto em Hengeveld (2004) e Hengeveld e Mackenzie (2008), ponderamos que os marcadores evidenciais, especificamente os de Evidencialidade Reportativa, possam também alocar os modalizadores volitivos em camadas mais altas do Nível Representacional, especificamente nas camadas do Episódio e do Conteúdo Proposicional, como podemos ver nas ocorrências (12) e (13):

(12) Un familiar de la residencia Albertia de Moratalaz dice que una doctora le dejó pasar el domingo al centro con una bata y guantes, para acompañar a su padre en sus últimas horas. En el pasillo de la planta donde estaba ingresado su padre vio trabajadores transportando bolsas de tamaño humano de color crema. "Me regañaban si salía de la habitación. Claro, no querían que viera los cadáveres", le dice a este periódico. ${ }^{14}$

(13) Abduelaziz lleva guantes y una mascarilla. "Normalmente vengo todos los días", explica. "Pero desde que empezó esto del coronavirus, vengo solo dos veces a la semana", nos cuenta como disculpándose. "Los habitantes de estos pueblos dependen de los suministros que nos llegan. En estos sitios no hay tiendas. Así que esperamos que todo vaya bien y no dejen de venir". ${ }^{15}$

\footnotetext{
14Tradução livre: Um parente da residência Albertia de Moratalaz diz que um médico o deixou passar o domingo no centro com uma túnica e luvas, para acompanhar seu pai nas últimas horas. No corredor da fábrica onde seu pai foi internado, ele viu trabalhadores transportando sacolas de tamanho humano de cor creme. "Eles me repreenderiam se eu saísse da sala. Claro, eles não queriam que eu visse os corpos", ele diz a este jornal. Disponível em: <https://elpais.com/espana/madrid/2020-03-18/las-residencias-seconvierten-enmorgues-no-querian-que-viera-los-cadaveres-en-las-bolsas-color-crema.html>. Acesso em: 19 mar. 2020.

${ }^{15}$ Tradução livre: Abduelaziz usa luvas e uma máscara. "Eu costumo ir todos os dias", explica ele. "Mas desde que essa coisa do coronavírus começou, eu venho apenas duas vezes por semana", diz ele se desculpando. "Os habitantes dessas cidades dependem dos suprimentos que chegam até nós. Nesses
} 
Em (12), o marcador de Evidencialidade Reportativa tem um escopo de atuação sobre a modalidade volitiva orientada para o Episódio que, para esta pesquisa, pode ser definida como a apreciação do falante (nesse caso, o sujeito introjetado no discurso pelo produtor da notícia) acerca do evento desejado (volição) pelo participante designado pelo predicado em um momento que é anterior ao evento de fala (preteridade). Desse modo, deparamo-nos com um caso em que o falante (produtor da notícia) reporta o que é apreciado pelo sujeito introjetado no discurso (Un familiar de la residencia Albertia de Moratalaz) em relação ao evento que não era desejado pelo participante expresso pelo predicado (no querían que viera los cadáveres), estando este evento sobre o escopo de um tempo absoluto (o que é marcado pelo emprego do pretérito imperfeito do indicativo, querían). Nesses casos, há uma tripla objetivação [+++objetivação], em que o falante (produtor da notícia) reporta a apreciação do sujeito introjetado em seu discurso em relação ao evento desejado por outrem em um momento que é anterior ao evento de fala (preteridade) e de aspecto realis, o que resulta em um maior grau de objetivação da modalização volitiva veiculada na notícia.

Em (13), o marcador de Evidencialidade Reportativa tem um escopo de atuação sobre uma modalidade volitiva com orientação para a Proposição, haja vista que o evento sobre o qual recai a volição e que é reportada pelo falante (produtor da notícia) se refere a algo possível apenas em um mundo do qual apenas o sujeito introjetado tem acesso (mundo imaginário/fictício), em que o evento manifestado é verdadeiro e realizável do ponto de vista não-factual. Nesse caso, averiguamos que o falante (produtor da notícia) reporta o que é desejado pelo sujeito introjetado no discurso (Abduelaziz) em relação à proposição sobre a qual recai o valor modal volitivo (que todo vaya bien y no dejen de venir). Nesses casos, há um certo grau de objetivação [+objetivação], em que o falante (produtor da notícia) se restringe a reportar a volição pessoal do sujeito introjetado no discurso que, por seu lado, é relativa à proposição (comprometimento volitivo do sujeito

lugares não há lojas. Então, esperamos que tudo corra bem e que eles não parem de vir”. Disponível em: <https://elpais.com/sociedad/2020-03-17/la-espana-que-ya-estaba-encuarentena.html>. Acesso em: 19 mar. 2020. 
em termos do que é desejado, pois é avaliado por ele como sendo algo bom e agradável) que contém o evento volicionado.

No tocante à Evidencialidade Dedutiva, encontramos apenas casos em que esta teve um escopo de atuação sobre modalizações volitivas com orientação para o Participante, como na ocorrência (14):

(14) Las puertas del Ayre Gran Hotel Colón siguen cerradas el miércoles a primera hora de la tarde. Ni rastro de clientes dentro ni de movimiento en el exterior. Se ve a trabajadores en el interior a través de las puertas de cristal, pero no quieren ni abrir ni hacer declaraciones. ${ }^{16}$

Em (14), o marcador de Evidencialidade Dedutiva apresenta um escopo de atuação sobre uma modalidade volitiva orientada para o Participante. Nesse caso, o falante (produtor da notícia) é assertivo em apresentar os conhecimentos prévios (Se ve a trabajadores en el interior a través de las puertas de cristal) acerca do conteúdo da notícia, em que o uso da marca de impessoalização (partícula se) remonta a uma fonte da informação que é externa a ele, no que se trata da indesejabilidade do participante designado pelo predicado (no quieren ni abrir ni hacer declaraciones). Dessa forma, atestamos uma dupla objetivação [++objetivação], pois o falante baseia a sua dedução com base nos conhecimentos de outrem (por meio da marca de impessoalização com a partícula se) que, por seu lado, expressa a (in)desejabilidade do participante designado pelo predicado em (não) realizar o evento sobre o qual recai a volição.

Em resumo, apresentamos o Quadro 3 com as considerações acerca da Evidencialidade e da modalidade volitiva:

Quadro 3: Evidencialidade e modalidade volitiva

\begin{tabular}{|c|c|c|}
\hline Marcador de Evidencialidade & Orientação modal volitiva & $\begin{array}{c}\text { Grau de objetivação e } \\
\text { escopo de atuação do } \\
\text { marcador evidencial }\end{array}$ \\
\hline $\begin{array}{c}\text { Reportativa } \\
\text { (Conteúdo Comunicado) }\end{array}$ & $\begin{array}{c}\text { Modalidade deôntica orientada } \\
\text { para a Proposição } \\
\text { (Conteúdo Proposicional) }\end{array}$ & $\begin{array}{c}\text { [Cobivaça] }] \\
\text { p ] }\end{array}$ \\
\hline
\end{tabular}

\footnotetext{
${ }^{16}$ Tradução livre: As portas do Ayre Gran Hotel Colón ainda estão fechadas na quarta-feira no início da tarde. Nenhum sinal de clientes dentro ou movimento fora. Os trabalhadores são vistos do lado de dentro através das portas de vidro, mas não querem abrir ou fazer declarações. Disponível em: <https://elpais.com/espana/madrid/2020-03-18/la-comunidad-de-madrid-activa-cientosde-camas-endos-hoteles-para-atender-a-contagiados-leves.html>. Acesso em: 19 mar. 2020.
} 


\begin{tabular}{|c|c|c|}
\hline $\begin{array}{c}\text { Reportativa } \\
\text { (Conteúdo Comunicado) }\end{array}$ & $\begin{array}{c}\text { Modalidade volitiva orientada } \\
\text { para o Episódio } \\
\text { (Episódio) }\end{array}$ & $\begin{array}{c}{[+++ \text { objetivação] }} \\
{[\mathrm{C}>\mathrm{ep}]}\end{array}$ \\
\hline Reportativa & $\begin{array}{c}\text { Modalidade volitiva orientada } \\
\text { para o Evento } \\
\text { (Estado-de-Coisas) }\end{array}$ & $\begin{array}{c}\text { [++objetivação] } \\
{[\mathrm{C}>\mathrm{e}]}\end{array}$ \\
\hline (Conteúdo Comunicado) & $\begin{array}{c}\text { Modalidade volitiva orientada } \\
\text { para o Participante } \\
\text { (Propriedade Configuracional) }\end{array}$ & $\begin{array}{c}\text { [++objetivação] } \\
{[\mathrm{C}>\mathrm{f}]}\end{array}$ \\
\hline Reportativa \\
(Conteúdo Comunicado) & $\begin{array}{c}\text { Modalidade deôntica orientada } \\
\text { para o Participante } \\
\text { (Propriedade Configuracional) }\end{array}$ & $\begin{array}{c}\text { [++objetivação] } \\
{[\mathrm{ep}>\mathrm{f}]}\end{array}$ \\
\hline Dedutiva & (Episódio) & \\
\hline
\end{tabular}

Fonte: Elaborado pelo autor

Sabendo-se dos casos de Evidencialidade e modalidade volitiva, passaremos, na subseção seguinte, para os casos de Evidencialidade e modalidade facultativa.

\subsection{Evidencialidade e modalidade facultativa}

Em relação à Evidencialidade e à modalidade facultativa, constatamos que os marcadores evidenciais, que operam na camada do Conteúdo Comunicado (Evidencialidade Reportativa), apresentam um escopo de atuação sobre modalizações facultativas com orientação para o Evento (Estado-de-Coisas) e o Participante (Propriedade Configuracional), como podemos ver, respectivamente, nas ocorrências (15) e (16):

(15) El presidente de este organismo, Nino Cartabellotta, habla de un "número enorme" de contagios entre los profesionales de la medicina en Italia y explica por qué esa situación es tan alarmante: "Si se enferman los profesionales que están en primera línea en esta emergencia, el servicio sanitario no podrá asegurar la asistencia a la población”. ${ }^{7}$

(16) Así lo advirtió este lunes el director del organismo, Tedros Adhanom Ghebreyesus: "No podremos frenar esta pandemia si no sabemos quién está infectado. El mensaje es simple para todos los países: hagan los test en cada caso sospechoso". ${ }^{18}$

\footnotetext{
${ }^{17}$ Tradução livre: O presidente desta organização, Nino Cartabellotta, fala sobre um "número enorme" de infecções entre profissionais médicos na Itália e explica por que essa situação é tão alarmante: "Se os profissionais que estão na linha de frente ficam doentes nesta emergência, o serviço de saúde não poderá garantir a assistência à população". Disponível em: <https://elpais.com/sociedad/2020-03-18/italiaregistra-un-nuevo-record-con-475-fallecidos-en-24-horas.html>. Acesso em: 19 mar. 2020.

${ }^{18}$ Tradução livre: Isso foi declarado na segunda-feira pelo diretor da organização, Tedros Adhanom Ghebreyesus: "Não conseguiremos parar essa pandemia se não soubermos quem está infectado. A mensagem é simples para todos os países: faça os testes em cada caso suspeito". Disponível em: $<$ https://elpais.com/ciencia/2020-03-19/asi-funcionan-los-tests-del-coronavirus.html>. Acesso em: 19 mar. 2020.
} 
Em (15), constatamos um caso de modalidade facultativa orientada para o Evento que, de acordo com Hengeveld (2004), diz respeito às circunstâncias externas e às capacidades físicas que possibilitam a concretização de um evento, mas sem que o falante faça uma avaliação pessoal dessa possibilidade. Nesse caso, atestamos que o marcador de Evidencialidade Reportativa, ao ter um escopo de atuação sobre uma modalidade facultativa orientada para o Evento, parece indicar uma dupla objetivação [++objetivação], já que remete ao que é reportado pelo sujeito introjetado no discurso (El presidente de este organismo, Nino Cartabellotta) e ao estatuto objetivo do evento sobre o qual recai a facultatividade (valor modal facultativo) expressa (el servicio sanitario no podrá asegurar la asistencia a la población) que, por sua vez, é reportada na fala do sujeito introjetado.

Em (16), averiguamos um caso de modalidade facultativa orientada para o Participante que, segundo Hengeveld (2004), está relacionada à manifestação das capacidades intrínsecas ou adquiridas do participante designado pelo predicado em termos da possibilidade de realização do evento sobre o qual recai a facultatividade (valor modal facultativo) manifestada. Nesse caso, constatamos que o marcador de Evidencialidade Reportativa, ao ter um escopo de atuação sobre a modalidade facultativa com orientação para o Participante, parece também apontar para uma dupla objetivação [++objetivação] no que diz respeito à discursividade do falante (produtor da notícia), haja vista que ele veicula o que é reportado pelo sujeito introjetado no discurso (Tedros Adhanom Ghebreyesus) que, por sua vez, manifesta a incapacidade do sistema público de saúde espanhol (o que é evidenciado pela marca de primeira pessoa do plural, nosotros) em relação ao evento sobre o qual recai a facultatividade (frenar esta pandemia si no sabemos quién está infectado).

No tocante à Evidencialidade Dedutiva, encontramos apenas casos em que esta teve um escopo de atuação sobre modalizações facultativas com orientação para o Participante, como na ocorrência (17):

(17) Este martes, además, la lluvia y la nieve completan el inquietante paisaje. No hay nadie. Literalmente nadie. "En realidad sí que están", dice Miguel Ángel protegido de la lluvia en un pequeño garaje a la entrada del pueblo. "Pero están en casa. Tienen miedo. Nadie sale". 
Uno podría pensar que, aislados del resto, los vecinos de estos pueblos seguirían con su vida normal. ${ }^{19}$

Em (17), o marcador de Evidencialidade Dedutiva apresenta um escopo de atuação sobre uma modalidade facultativa orientada para o Participante. Nesse caso, o falante (produtor da notícia) é assertivo em apresentar a obtenção dos conhecimentos prévios (“En realidad sí que están”, dice Miguel Ángel protegido de la lluvia en un pequeño garaje a la entrada del pueblo. "Pero están en casa. Tienen miedo. Nadie sale") que, por sua vez, advém de uma fonte que é externa a ele, ou seja, oriunda de um terceiroreportado (Miguel Ángel) mencionado no discurso. A partir dos conhecimentos obtidos dessa fonte da informação, o falante (produtor da notícia) é capaz de deduzir a capacidade do participante expresso pelo predicado (Uno) em concretizar o evento sobre o qual recai a facultatividade (pensar que, aislados del resto, los vecinos de estos pueblos seguirían con su vida normal), em que o uso do condicional simples do espanhol (podría) parece indicar essa apreciação do falante (fonte da dedução). Nesse caso, atestamos um menor grau de objetivação [-objetivação], se considerarmos que o falante é quem deduz a capacidade inerente ao participante expresso, ainda que essa dedução esteja baseada em informações repassadas por terceiros.

Por fim, apresentamos o Quadro 4 com as considerações acerca da Evidencialidade e da modalidade facultativa:

Quadro 4: Evidencialidade e modalidade facultativa

\begin{tabular}{|c|c|c|}
\hline Marcador de Evidencialidade & Orientação modal facultativa & $\begin{array}{c}\text { Grau de objetivação e } \\
\text { escopo de atuação do } \\
\text { marcador evidencial }\end{array}$ \\
\hline $\begin{array}{c}\text { Reportativa } \\
\text { (Conteúdo Comunicado) }\end{array}$ & $\begin{array}{c}\text { Modalidade facultativa orientada } \\
\text { para o Evento } \\
\text { (Estado-de-Coisas) }\end{array}$ & $\begin{array}{c}\text { [++objetivação }] \\
{[\mathrm{C}>\mathrm{e}]}\end{array}$ \\
\hline $\begin{array}{c}\text { Reportativa } \\
\text { (Conteúdo Comunicado) }\end{array}$ & $\begin{array}{c}\text { Modalidade facultativa orientada } \\
\text { para o Participante } \\
\text { (Propriedade Configuracional) }\end{array}$ & $\begin{array}{c}\text { [++objetivação] } \\
{[\mathrm{C}>\mathrm{f}]}\end{array}$ \\
\hline
\end{tabular}

\footnotetext{
${ }^{19}$ Tradução livre: Além disso, nesta terça-feira, a chuva e a neve completam a paisagem perturbadora. Não há ninguém. Literalmente ninguém. "Eles realmente são", diz Miguel Ángel, protegido da chuva em uma pequena garagem na entrada da cidade. "Mas eles estão em casa. Tem medo. Ninguém sai." Alguém poderia pensar que, isolados do resto, os moradores dessas cidades continuariam com suas vidas normais. Disponível em: <https://elpais.com/sociedad/2020-03-17/la-espana-que-ya-estaba-encuarentena.html>. Acesso em: 19 mar. 2020.
} 


\begin{tabular}{|c|c|c|}
\hline $\begin{array}{c}\text { Dedutiva } \\
\text { (Episódio) }\end{array}$ & $\begin{array}{c}\text { Modalidade facultativa orientada } \\
\text { para o Participante } \\
\text { (Propriedade Configuracional) }\end{array}$ & $\begin{array}{c}\text { [-objetivação] } \\
{[\mathrm{ep}>\mathrm{f}]}\end{array}$ \\
\hline
\end{tabular}

Fonte: Elaborado pelo autor

Com base nos resultados e discussões obtidos nesta seção, constatamos que a Evidencialidade pode ser uma categoria linguística condicionadora da Modalidade, considerando que os marcadores evidenciais das camadas mais altas (Conteúdo Comunicado e Episódio) apresentam um escopo de atuação sobre os subtipos modais (as modalidades epistêmica, deôntica, volitiva e facultativa) que atuam nas camadas mais baixas a eles no Nível Representacional (Conteúdo Proposicional, Episódio, Estadode-Coisas e Propriedade Configuracional), podendo manifestar certo grau de objetivação dos conteúdos modais subjetivos ou asseverar o grau de objetivação dos conteúdos modais objetivos.

\section{Considerações finais}

A análise qualitativa do condicionamento da Evidencialidade em relação à Modalidade nas notícias do jornal El País revelou que os marcadores evidencias Reportativos e Dedutivos apresentaram um escopo de atuação sobre os subtipos modais (as modalidades epistêmica, deôntica, volitiva e facultativa) e, consequentemente, sobre os modalizadores que atuam nas camadas do Nível Representacional (Conteúdo Proposicional, Episódio, Estado-de-Coisas e Propriedade Configuracional); considerando que o marcador evidencial operava sempre em uma camada mais acima, confirmando, portanto, a hipótese defendida nesta pesquisa.

Em termos argumentativos, identificamos que os marcadores evidenciais Reportativos podem objetivar os conteúdos modais subjetivos, no caso da modalidade epistêmica, ao atuar na camada do Conteúdo Proposicional, e das modalidades deôntica e volitiva, ao atuarem na camada do Episódio; e asseverar a objetivação dos conteúdos modais objetivos, no que diz respeito às modalidades deôntica, volitiva e facultativa, ao atuarem nas camadas do Estado-de-Coisas e da Propriedade Configuracional. 
Ponderamos que, ao reportar os conteúdos modais subjetivos de terceiros, o autor da notícia pretenda não apenas revelar que se trata do material cognitivo de terceiros, mas reportar, de maneira clara, precisa e objetiva, as crenças e opiniões subjetivas dos sujeitos introjetados no discurso, descomprometendo-se, assim, com o conteúdo modal veiculado.

Em relação aos marcadores evidenciais Dedutivos, estes apontam para uma menor objetivação dos conteúdos modais expressos na notícia, haja vista que são instaurados no texto a partir de alguma evidência disponível e com base na percepção do autor dos fatos relatados.

Acreditamos que a não-identificação de marcadores de Evidencialidade Inferencial se deva ao próprio gênero notícia em si, posto que, na veiculação dos fatos e das opiniões de terceiros, busca-se a objetivação do conteúdo apresentado, o que não poderia proporcionar que o falante (produtor da notícia) viesse a emitir algum tipo de avaliação pessoal acerca dos conteúdos modais instaurados, sendo, portanto, necessária a investigação desse condicionamento em gêneros de caráter opinativo que pudessem sanar essa lacuna não preenchida nesta pesquisa.

\section{Referências}

ARENA, Ana Beatriz. Construções comparativas em perspectiva funcional: Argumentação, modalização e evidencialidade. Revista Guavirá Letras, 2015. Disponível em: <http://websensors.net.br/seer/index.php/guavira/article/viewFile /204/178>. Acesso em: 23 mar. 2020.

CARIOCA, Cláudia Ramos. A integração dos aspectos sintáticos, semânticos e pragmático-discursivos na manifestação da evidencialidade. Revista Entrepalavras, v. 8, p. 112-129, 2018. Disponível em: <http://www.entrepalavras .ufc.br/revista/index.php/Revista/article/view/1204/537>. Acesso em: 23 mar. 2020. HATTNHER, M. M. D. A. A expressão lexical da evidencialidade: reflexões sobre a dedução e a percepção de evento. Revista Entrepalavras, v. 8, n. esp., 2018, p. 98-111. Disponível em: <http://www.entrepalavras.ufc.br/revista/index.php/Revista/ 
article/view/1244/538>. Acesso em: 23 mar. 2020.

HENGEVELD, K. Mood and modality. In: GEERT BOOIJ, Christian; LEHMANN, Joachim Mugdan (Org.). Morphology: A handbook on inflection and word formation. Berlin: Mouton de Gruyter, p. 1190-1202, 2004.

. The grammaticalization of tense and aspect. In: NARROG, Heiko; HEINE, Bernd (Org.). The Oxford handbook of grammaticalization. Oxford: Oxford University Press, p. 580-594, 2011.

.; HATTNHER, M.M.D.A. Four types of evidentiality in the native languages of Brazil. Linguistics, v. 53, p. 479-524, 2015. Disponível em: <https://www.degruyter.com/view/journals/ling/53/3/article-p479.xml>. Acesso em: 23 mar. 2020.

.; MACKENZIE, L. Functional Discourse Grammar: A typologically based theory of language structure. Oxford: Oxford University Press, 2008.

LOURENÇO, Fabiana Pirotta Camargo. O condicional de valor evidencial no domínio jornalístico. Revista Estudos Linguísticos, v. 46, n. 2, p. 655-669, 2017. Disponível em: <https://revistas.gel.org.br/estudos-linguisticos/article/view/1684 /1248>. Acesso em: 23 mar. 2020.

Recebido em 03/04/2020. Aprovado em 28/05/2020. 